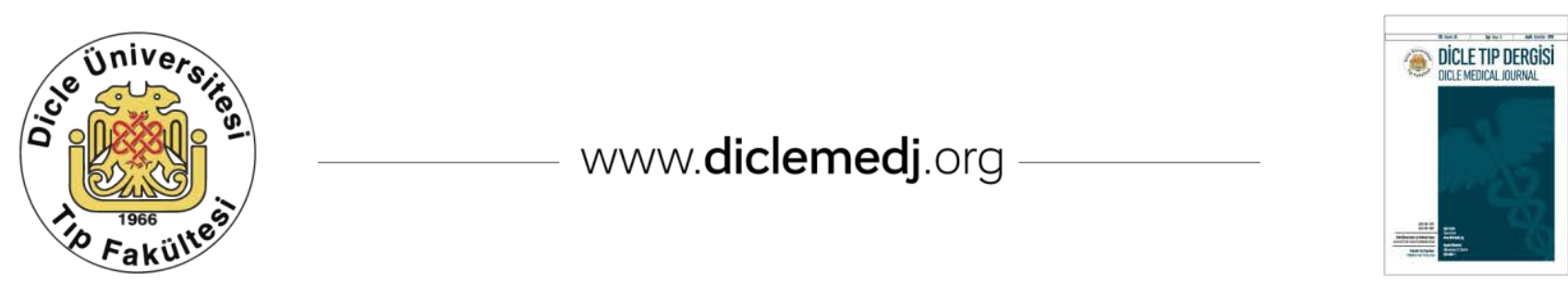

Original Article / Özgün Araştırma

\title{
Evaluation Of The Median And Paramedian Approach In Spinal Anesthesia In Elderly Patients
}

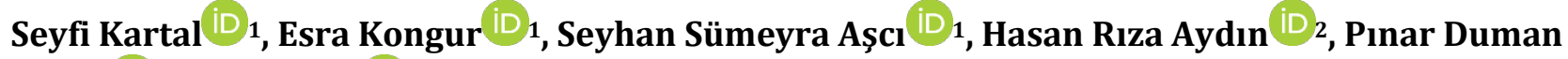 \\ Aydın $D_{1}$, Ahmet Şen ${ }_{1}$ \\ 1 Department of Anesthesiology and Reanimation, Trabzon Kanuni Education and Research Hospital, University of Healthy Sciences, Trabzon, \\ Turkey \\ 2 Department of Urology, Trabzon Kanuni Education and Research Hospital, University of Healthy Sciences, Trabzon, Turkey \\ Received: 30.09.2019; Revised: 31.03.2020; Accepted: 13.04.2020
}

\begin{abstract}
Objective: Spinal anesthesia is frequently used in many surgical procedures. Although both median and paramedian approaches are used in spinal anesthesia, the conventional median approach is preferred. Reportedly, degenerative changes in elderly patients are less affected by the paramedian approach during spinal anesthesia. In this study, we aim to determine which of the two methods is superior in elderly patients.
\end{abstract}

Method: This study, patients were treated with the median approach or paramedian approach during spinal anesthesia after appropriate procedural preparation.

Results: Overall, 103 patients were included in the study. The success rate was 90.5\% in the paramedian approach and $79.1 \%$ in the median approach. The duration of the procedure was shorter in the paramedian approach than in the median approach $(14.4 \pm 8.2$ versus $28.4 \pm 24.9, \mathrm{p}=0.004)$. During the procedure, the repetition from another interval was more in the median approach than in the statistically insignificant level due to the contact with the spinal bones and failure. The average age of the patients with the procedure duration was < $30 \mathrm{~s}$ was higher than those with procedure duration $\geq 30 \mathrm{~s}$.

Conclusions: In elderly patients, the success rate of the paramedian approach in the first attempt and repeated trials increased, the procedure time was shortened, and the surgery could be performed more comfortably without touching the spinal bones independent of the flexion position. Therefore, we believe that the paramedian approach is a faster, safer, and more successful method compared with the median approach in elderly patients.

Keywords: Spinal anesthesia, median, paramedian, geriatric patient.

DOI: 10.5798/dicletip.748556

Correspondence / Yazışma Adresi: Seyfi Kartal, Department of Anesthesiology and Reanimation, Trabzon Kanuni Education and Research Hospital, University of Healthy Sciences, Trabzon, Turkey e-mail: drseyfikartal@gmail.com 


\section{Yaşlı Hastalardaki Spinal Anestezide Median ve Paramedian Yaklaşımın Değerlendirilmesi Öz}

Giriş: Spinal anestezik pek çok cerrahi işlemde sıklıkla kullanılır. Spinal anestezide median ve paramedian yaklaşım kullanılmasına rağmen, geleneksel median yöntem daha çok tercih edilir. Spinal anestezideki paramedian yaklaşım yaşlılardaki dejeneratif değişikliklerden daha az etkilenmektedir. Bu çalışmada yaşlılarda iki yöntemden hangisinin üstün olduğunu değerlendirmeyi amaçlamaktayız.

Yöntemler: Bu çalişmada hastalara uygun hazırlık sonrası median ve paramedian yaklaşım ile spinal anestezik uygulandı.

Bulgular: Çalişmaya toplam 103 hasta dahil edildi. Başarı oranı paramedian yaklaşımda \%90,5 iken median yaklaşımda \%79,1 olarak bulundu. İşlem süresi paramedian yaklaşımda median yaklaşımdan daha kısa idi $(14.4 \pm 8.2$ 'e karşın 28.4 $\pm 24.9, \mathrm{p}=0.004$ ). İşlem esnasında spinal kemiklere değme ve başarısızlık nedeniyle başka aralıktan deneme istatistiksel olarak anlamlı düzeyde olmasa da median yaklaşımda daha fazla idi. İşlem süresi 30 sn den az olanların yaş ortalaması, 30 sn den fazla olanlara göre daha yüksek idi.

Sonuç: Yaşlı hastalarda paramedian yaklaşımda, ilk girişimde ve tekrarlayan denemelerdeki başarı oranı yüksek, işlem süresi kısa, fleksiyon pozisyonundan bağımsız olarak spinal kemiklere değmeden hasta için daha konforlu şekilde işlem yapılabilmektedir. Bu nedenle yaşlı hastalarda median yaklaşıma göre paramedian yaklaşım hızlı, güvenli ve daha başarılı şekilde uygulanabilen bir yöntem olduğu kanısındayız.

Anahtar kelimeler: Spinal anestezi, median, paramedian, yaşlı hasta.

\section{INTRODUCTION}

Spinal anesthesia (SA), also known subarachnoid block, is a type of neuroaxial anesthesia. SA is provided by applying local anesthetics and opioid drugs to the subarachnoid space ${ }^{1}$. SA is frequently used in lower abdominal, inguinal, urogenital, rectal, and lower extremities surgeries ${ }^{2}$. Due to rapid recovery from surgery, early mobilization and discharge, low incidence of pulmonary embolism and venous thrombosis, less surgical bleeding and need for transfusion, and early return of intestinal functions, SA is preferred over general anesthesia ${ }^{2}$. SA also has disadvantages, such as post-spinal headache, spinal hematoma, injury to nerve fibers ${ }^{3}$, pain during the procedure, infection, meningitis, and subdural hematoma ${ }^{4}$.

For epidural anesthesia, which is another type of neuroaxial block, several auxiliary tools and techniques have been described. However, SA can only be performed with a median approach (MA) and a paramedian approach (PA) ${ }^{5}$. The MA is the most widely used method6; however, this approach is painful and difficult to apply in elderly patients due to degenerative changes in the vertebrae ${ }^{7}$. Additional changes occur in elderly patients such as decrease in joint distance, limitation of joint movements, and increase in osteophytes. PA is recommended in elderly patients since it is less affected by such degenerative changes ${ }^{8}$.

There are few studies on the use of the MA or PA in SA for elderly patients. However, it is not yet known which of these two methods is superior in elderly patients where degenerative changes are expected. Therefore, in this study we aim to evaluate the MA and PA approach in elderly patients in terms of success rate, number of attempts, intervention from another institute due to failure in the first institute, duration of the procedure, patient's comfort, and switching to the other method in case of failure and the respective success rate.

\section{METHODS}

This study was conducted within 2 years after the approval of Local Clinical Research Ethics Committee (2018/39) and patient's consent 
forms. Patients aged $>70$ years and who underwent urological or orthopedic surgery under SA and in the risk classification of American Society of Anesthesiologists (ASA) 1-3 were included this study. 103 patients were evaluated prospectively.

In our clinic, as a part of the SA protocol, preanesthetic evaluation was performed by anesthesiologists $24 \mathrm{~h}$ prior to the application of anesthesia; routine patient anesthesia consent form was also obtained. Patients were taken into the premedication room after $\geq 6$ hours of fasting, $500 \mathrm{~mL}$ crystalloid (Ringer's Lactate) solution was given intravenously in the last 30 minutes. After being taken to the operation table for the procedure, the patients were continuously monitored by electrocardiography, noninvasive blood pressure and oxygen saturation was measured using pulse oximetry. Prior to the procedure, patients were given $0.02-0.5 \mathrm{mg} / \mathrm{kg}$ midazolam and $0.5-1.0 \mu \mathrm{g} / \mathrm{kg}$ fentanyl. After proper cleaning, patients were flexed 15-20 degrees forward in the sitting position by a medical personnel. Anesthesia was administered in the L3-4 spinal space for this study. In our clinic, $22 \mathrm{G}$ Quincke needles (Spinocan; B. Braun, Melsungen, Germany) are used for elderly patients (aged $>60$ years). The MA was performed in a conventional manner. For this, patients is given forward flexion position and the needle is entered into the spinal space from the midline. The PA for SA was performed at a distance that is $1 \mathrm{~cm}$ lateral and $1 \mathrm{~cm}$ caudal from the planned vertebral space point, and is advanced through 10-15 degrees medial and 60 degrees cephal. If MA was unsuccessful despite three attempts, the PA was used and vice versa. It the alternative approach was unsuccessful, a different specialist provided the anesthesia. Surgery was permitted after attaining an adequate block levels. If the procedure was unsuccessful or there was not enough block, a different method of anesthesia (general anesthesia) was used.
The following patients were excluded from the study: those who are traded in another position except sitting; those regularly using opioids or other non-steroid antiinflammatory drugs; those with a history of allergy to any drug used in the study; those with contraindications to SA; those with drug addiction; obese patients (body mass index $\geq 35$ ); those with migraine and chronic headache; and those who underwent general anesthesia when SA was unsuccessful despite repeated attempts. The study included patients aged $>70$ years and who were not contraindicated for SA (bleeding diathesis, use of blood thinners, serious heart disease, serious orthopedic problem, local infection at the site of surgery). The data were evaluated by a researcher other than the SA physician. Demographic data, type of operation, use of the MA or PA in SA, and the number of repeated attempts for the procedure were evaluated.

Statistical analysis was performed using the Statistical Package for Social Sciences software, version 17.5. For analyzing the data, frequency (f) and percentage (\%) of distribution were evaluated first. The suitability of the groups for normal distribution was examined using the One Sample Kolmogorov Smirnov Test. The Mann-Whitney $U$ test was applied to determine the difference between the two groups. The Kruskal-Wallis $\mathrm{H}$ test was applied to investigate the difference in more than two groups. After the Kruskal-Wallis $\mathrm{H}$ test, the homogeneity of the group distribution was checked with the Levene's test; based on the variables, the post-hoc Tukey's honestly significant difference test was used to determine in between which groups it was differed. The comparison of qualitative data was performed by using the Chi-square test. $\mathrm{p}<0.05$ level was considered significant. 


\section{RESULTS}

Overall, 103 patients were included in this study. Of these, 53 (51.4\%) patients underwent the PA. In five patients, the PA failed and the MA was used; thereafter, the procedure was completed. Fifty patients underwent the MA; upon failure in 12 patients, the PA was applied and the procedure was completed successfully.

There was no difference between the groups in terms of age and number of attemptsThe duration of process was shorter in the PA ( $p$ $=0.004$; Table 1 ).

During the procedure, $60 \%$ of the patients who underwent surgery without touching the bone with the spinal needle underwent the PA; the remaining $40 \%$ of the patients underwent the MA. However, the difference between the two groups was not statistically significant $(p<0.05$; Table 2$)$. A total of
$51.9 \%$ of the patients who were attempted from another space due to failure were in the MA group and $48.1 \%$ were in the PA group; however, the difference between the groups was not statistically significant ( $\mathrm{p}>0.05$; Table 2).

Table I: Various findings of MA and PA.

\begin{tabular}{|c|c|c|c|}
\hline & $\begin{array}{l}\text { MA Group } \\
(n=38)\end{array}$ & $\begin{array}{l}\text { PA Group } \\
(n=48)\end{array}$ & $p$ \\
\hline Age (years) & $75.8 \pm 6.0$ & $76.3 \pm 5.5$ & NS \\
\hline $\begin{array}{l}\text { Duration of } \\
\text { process (sec) }\end{array}$ & $28.4 \pm 24.9$ & $14.4 \pm 8.2$ & 0.004 \\
\hline $\begin{array}{l}\text { Number of } \\
\text { attempts }\end{array}$ & $1.5 \pm 0.7$ & $1.4 \pm 0.7$ & NS \\
\hline
\end{tabular}

as (n). MA: Median approach PA: Paramedian approach

Table II: Various data in MA and PA

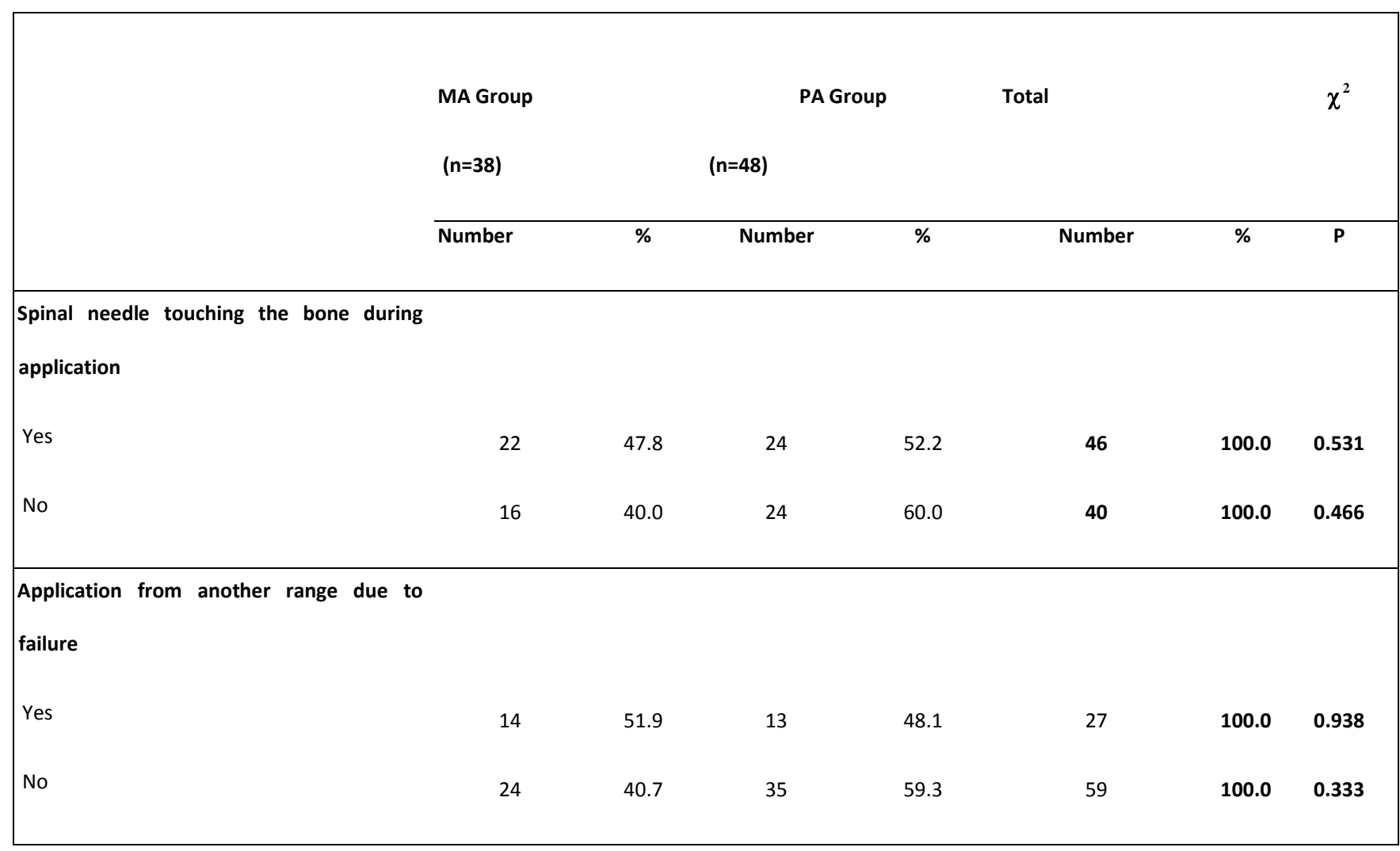


The age average of the patients with a procedure duration $<30 \mathrm{~s}$ was found to be higher than the patients with a procedure duration $\geq 30$ s. $(76.58 \pm 6.2$ versus $74.37 \pm 2.9, \mathrm{P}=$ 0.000; Table 3).

Table III: The Mann-Whitney U test results were used to determine if the processing times differed according to the age variable (n: 86).

\begin{tabular}{|c|c|c|c|}
\hline & \multicolumn{3}{|c|}{ Duration of process (sec) } \\
\hline & $\begin{array}{l}\text { Less than } \\
\qquad \begin{array}{l}30 \mathrm{sec} \\
(n=67)\end{array}\end{array}$ & $\begin{array}{l}30 \text { sec and } \\
\text { above } \\
(n=19)\end{array}$ & $p$ \\
\hline Age & $76.58 \pm 6.2$ & $74.37 \pm 2.9$ & $0.000^{*}$ \\
\hline
\end{tabular}

\section{DISCUSSION}

SA is frequently preferred because of the reduction in postoperative morbidity and other complications in lower abdominal and lower extremity surgeries. SA can be performed with the MA or PA. The success of SA and epidural anesthesia varies depending on the surgeon's ability and experience, as well as the anatomical characteristics of the patient ${ }^{5}$.

The MA is the more preferred classical approach6. In the MA, supraspinous, interspinous, and ligamentum flavum are passed. In elderly patients, the procedure is painful and difficult due to their reduced ability to complete the flexion position due to the decrease in the distance between the joints, calcification, and degeneration ${ }^{7,9}$. In the PA, since the ligamentum flavum directly reaches from the paravertebral muscles instead of supraspinous and interspinous ligaments, problems due to degenerative change in elderly patients could be avoided ${ }^{10,11}$.

Bayındır et al. ${ }^{12}$ showed in their study with 80 patients that the success rate in the young middle-aged group (aged 30-40 years) was $70 \%$ with the PA and the $95 \%$ with the MA. In contrast, Rabinowitz et al. ${ }^{8}$ found that the success rate was $85 \%$ with the PA and $45 \%$ with the MA in their study in which 40 patients were included. In other similar studies, the success rate was found to be $100 \%$ with the PA and $90 \%$ with the $\mathrm{MA}^{9,10}$. In this study, the success rate was found to be $90.5 \%$ with the PA and $79.1 \%$ with MA, which is similar to studies $^{9,10,12}$.

Muranaka et al. ${ }^{11}$ reported that there was no difference in the success rate of the PA and MA $(89 \%$ versus $94 \%)$ in the first attempt. However, it was stated that longer spinal needles should be used for the PA. The success rate was found to be $90 \%$ with the PA and $70 \%$ with the MA by Sing et al. ${ }^{9}, 92 \%$ with the PA and $68 \%$ with the MA by Ali et al. ${ }^{7}$, and $60 \%$ with the by Ahsan ul-haq et al. ${ }^{10}$. In our study, the attempt from another space due to failure was not statistically significant, however, it was more with the MA. Although, the success rate our results were proportionally low, the ratio between PA and MA was similar to previous studies.

Bayındır et al. ${ }^{12}$ compared the duration of SA and the entire surgical procedure in young middle-aged (aged 30-40 years) patients and found that the number of attempts and the total time was longer with the PA compared with the MA; hypotension, bradycardia, nausea, and vomiting, the early complications of anesthesia, were observed more frequently with the PA than the MA, though not statistically significant. In this study, elderly patients were included (average age, $76.09 \pm 5$ years) and the procedure duration was shorter with the PA compared with the MA.

To attain the forward flexion position during the application of SA is particularly uncomfortable for patients with chronic pain and elderly patients ${ }^{8}$. The spinal needle touching the bone at the intervention site may also cause pain. Podder et al. ${ }^{13}$ reported that young patients (aged 30-40 years) with lower extremity trauma felt less pain during the PA. In our study, $60 \%$ of the patients who underwent SA without touching spinal bones during the procedure were in the PA group. 
Giving position for SA in elderly patients is a problematic process because it is painful and patient compliance is low. Both MY and PY are primarily applied in a classical sitting position, as the preparatory phase is simple and patient compliance is better. In our study, a sitting position was preferred for SA as in similar studies in the literature.6,7. Rabinowitz et al. ${ }^{8}$ have showed that the attempt rate from another space due to failure was $5 \%$ with the PA and $30 \%$ with the MA. In our study, we have found that the attempt rate from another space due to failure was $27 \%$ with the PA and $36.8 \%$ with the MA. Rabinowitz et al. ${ }^{8}$ conducted the study with 40 patients in the lateral decubitus position. Although the results of our study are similar to that of Rabinowitz et al., we believe that our rates are different due to the procedure being performed in the sitting position, different sample size, geographic and anatomical features of the patients, and personal experience and preferences of the surgeons regarding the method.

Post-spinal headache (PSH) is the most common complication of SA. In young patients, the risk increases with the size of the needle, the use of a sharp tip needle, and repeated puncture of the dura ${ }^{7}$. Firdous et al. $^{2}$ performed SA with the PA and MA by using a pencil pointtype needle in 120 patients undergoing cesarean section. They found that PSH complication was lower in the PA than MA (1.6\% versus $5 \%$ ) group, though this was not statistically significant. In a study by Haider et al. ${ }^{14}$, PSH in the PA group was found to be significantly lower than in the MA group (4\% versus $28 \%$ ). Mosaffa et al. ${ }^{15}$ found that PSH was similar in the PA and MA groups $(10.7 \%$ versus $9.3 \%$ ) in 150 patients aged undergoing orthopedic surgery in the middle age group. Bayındır et al. ${ }^{12}$ found PSH to be similar (8.7\%) in the PA and MA in young patients (aged 3040 years).

Sadeghi et al. ${ }^{16}$ found in their study that PSH was higher in the PA group (9.8\% versus $9.4 \%$ ) than in the MA group, though not statistically significant. Türker et al. ${ }^{17}$ conducted a study with 400 patients who underwent urological surgery; among the young patients (aged 30-40 years) PSH in the PA group was higher than in the MA group $(13 \%$ versus $8 \%, \mathrm{p}<0.05)$. However, it was reported that there was no difference in the development of PSH between the MA and PA in elderly patients. We have never found PSH in our study. Because, we believe that this condition is due to the advanced age of the patients.

In our study, the average age of the patients with procedure duration $<30 \mathrm{~s}$ was higher than those with a procedure duration $\geq 30 \mathrm{~s}(76.58 \pm$ 6.2 versus $74.37 \pm 2.9, p=0.000$ ). Therefore, we believe that the duration of the procedure may be shortened due to sedation and patient compliance. In addition, the decreased distance between the skin and the subarachnoid space due to the decrease in subcutaneous fat tissue and muscle mass in elderly patients shortens the procedure duration. Further extensive research is required to understand the correlation between the length of the procedure duration and age.

There are several limitations of this study. The first; this study single center and it was made by a few practitioners. The second, our study focuses on the ease of operation and the success of the procedure; the side effects of SA, such as paresthesia, insufficient block, hypotension, nausea, vomiting, bradycardia, and cardiac arrest were not evaluated. In addition, height, weight, the presence of rheumatic diseases such as ankylosing spondylitis, and anatomical variations of the vertebral column were also not determined.

\section{CONCLUSION}

In elderly patients, there is a direct access to the dura from the paravertebral muscles without encountering supraspinous and interspinous protrusions. Therefore, for the PA, the success rate, the chance of success in the first attempt increase, the duration of the procedure is shortened and more comfortably without touching the spinal bones. We believe that the PA is a faster, safer, and more 
successfully than the MA in elderly patients. More detailed and multicenter studies are required in the elderly patients.

\section{ACKNOWLEDGMENT}

We would like to thank Kürşat Yurdakos who helped us in the statistical evaluation of the study.

Ethics Committee Approval: This study was conducted within 2 years after the approval of Local Clinical Research Ethics Committee (2018/39) and patient's consent forms

Declaration of Conflicting Interests: The authors declare that they have no conflict of interest.

Financial Disclosure: No financial support was received.

\section{REFERENCES}

1. Cook TM, Counsell D, Wildsmith JA. Royal college of anaesthetists third national audit project. Major complications of central neuraxial block: report on the third national audit project of the royal college of anaesthetists. Br J Anaesth 2009; 102: 179-90.

2. Firdous T, Siddiqui MA, Siddiqui SM. Frequency of post dural puncture headache in patients undergoing elective cesarean section under spinal anesthesia with median versus paramedian approach. Anaesth Pain \& Intensive Care 2016; 20: 165-70.

3. Puolakka R, Haasio J, Pitkänen MT, et al. Technical aspects and postoperative sequelae of spinal and epidural anesthesia: a prospective study of 3,230 orthopedic patients. Reg Anesth Pain Med 2000; 25: 488-97.

4. Conroy PH, Luyet C, McCartney CJ, et al. Real-time ultrasound-guided spinal anaesthesia: a prospective observational study of a new approach. Anesthesiol Res Pract 2013; 2013: 525818.

5. S Kartal, B Kösem, H Kılınç, et al. Comparison of epidrum, epi-jet and loss of resistance syringe techniques for identifying the epidural space in obstetric patients. Niger J Clin Pract 2017; 20: 9927.

6. Wantman A, Hancox N, Howell PR. Techniques for identifying the epidural space: a survey of practice amongst anaesthetists in the UK. Anaesthesia 2006; 61: $370-5$.
7. Ali SM, Dash S, Mohapatra R. Spinal anaesthesia with median and paramedian approach in geriatric patients undergoing lower limb surgery IJMAS 2016; 3:130-5.

8. Rabinowitz A, Bourdet B, Minville V, et al. The paramedian technique: a superior initial approach to continuous spinal anesthesia in the elderly. Anesth Analg 2007; 105: 1855-7.

9. Singh P, Agrawal SK, Dwivedi S, et al. A comparative evaluation between median and paramedian approaches for sub-arachnoid block in elderly patients. Int J Res Med Sci 2016; 4: 2069-72.

10. Bayındır S, Özcan S, Koçyiğit F, et al. Which approach is preferred in spinal anesthesia: median or paramedian? Comparison of early and late complications. İstanbul Med J 2017; 18: 205-9.

11. Ahsan-ul-Haq M, Amin S, Javaid S. Paramedian technique of spinal anesthesia in elderly patients for hip fracture surgery. J Coll Physicians Surg Pak 2005; 15: 160-1.

12. Muranaka $\mathrm{K}$, Mizutani $\mathrm{H}$, Seo $\mathrm{K}$, et al. A comparison between midline and para median approaches for combined spinal-epidural anaesthesia. Masui 2001; 50: 1085-8.

13. Podder S, Kumar N, Yaddanapudi LN, et al. Paramedian lumbar epidural catheter insertion with patients in the sitting position is equally successful in the flexed and unflexed spine. Anesth Analg 2004; 99: 1829 -32.

14. Haider S, Butt KJ, Aziz M, et al. Post dural puncture headache-a comparison of midline and paramedian approaches. Biomedica 2005; 21: 90-2.

15. Mosaffa F, Karimi K, Madadi F, et al. Post-dural puncture headache: a comparison between median and paramedian approaches in orthopedic patients. Anesth Pain Med 2011; 1: 66-69.

16. Sadeghi A, Razavi SS, Gachkar L, et al. Comparison of the incidence of post spinal headache following median and para median approach in cesarean patients. J Iranian Soc. Anesthesiol Intens Care 2009; 31: 4-9.

17. Türker G, Gurbet A, Kelebek Girgin N, et al. Dura delinmesine bağlı başağrısı: Median ve paramedian yaklaşımların karşılaştırılması. Türk Anest Rean Der 2005; 33: 139. 